Rule-Following and Realism 



\section{Rule-Following and Realism}

\section{GARY EBbS}

HARVARD UNiversity PRESS

Cambridge, Massachusetts London, England 1997 
Copyright (c 1997 by the President and Fellows of Harvard College

All rights reserved

Printed in the United States of America

Library of Congress Cataloging-in-Publication Data

Ebbs, Gary.

Rule-following and realism / Gary Ebbs.

p. $\mathrm{cm}$.

Includes bibliographical references and index.

ISBN 0-674-78031-0 (hardcover : alk. paper)

1. Meaning (Philosophy)-History-20th century. 2. Language and languages-Philosophy. 3. Realism-Controversial literature.

I. Title.

B840.E23 1997

$121^{\prime} .68-\mathrm{dc} 21$

96-51880 